\title{
Environmental Awareness Among Secondary School Students Of Golaghat District In The State Of Assam And Their Attitude Towards Environmental Education
}

\author{
Kumud Ghosh, \\ Assistant Professor, Education Department, Nakachari College, Nakachari-785635, Jorhat-Assam.
}

\begin{abstract}
The present study attempts to study the level of environmental awareness and attitudes towards environmental education among Secondary School students of Golaghat district in the state of Assam. The sample consisted of 200 students which includes 100 boys and 100 girls. The Descriptive Survey Method was employed for the present study. Environmental awareness, attitude and socio-economic scale was developed and standardized for the present study. The data was statistically analyzed by using ' $z$ ' test and Karl Pearson's coefficient of correlation (' $r$ '). Environmental awareness and attitude towards environmental education among the Secondary School male and female students was found not significant; but in case of rural and urban student the attitude towards environmental education was found significant. The relationship between environmental awareness and attitudes towards environmental education among the students was found strong and positive.
\end{abstract}

Key Words: Secondary School, Environmental awareness, Attitude, Socio-economic status.

\section{Introduction:}

Mankind's encounter with the environment is as old as the man himself. Since the evolution of man on the earth he has been dependent on the environment. Initially need of man limited and small; therefore, the activities of man did not affect the environment. But slowly human being settled down and civilized himself and learnt to cultivate. Over recent decades, global problems relating to degradation of natural resources and pollution have increased dramatically. Natural resources are depleted by excessive use.

Environment is the sum total of all conditions and influences of the development of the life of human being and other organisms. It includes air, water, land dynamically the interrelationship that exists between these and human beings; other living creatures, plants, microorganisms and property. The word environment embraces the conditions or influences under which any organism or thing exists, lives or develops. All these may be placed into three divisions such as the set of physical conditions affecting and influencing the growth and development of an individual and community; the social and cultural conditions affecting the nature of an individual or community; and the surroundings of an inanimate object of intrinsic social value. Therefore, environment includes all the conditions, circumstances and influences surrounding and affecting an organism or a group of organisms (Trivedi and Raj, 1992). So, it may be stated that the concept of environment in its totality is a complex one, far ranging in its implications and challenging to our understanding.

Over the last 50 years, environmental education (EE) has been one of the main interests of school organizations, local communities, the private sectors and local governments. These organizations have been demanding that schools should include EE in the curriculum of education. Many authors name the 1960s as the decade when EE started to develop in response to the world's growing awareness about environmental problems. Others believe that EE grew from the movement that existed from the beginning of the last century such as nature study, conservation and outdoor education (NACD, 1998).

One of the most widely accepted definitions of EE was given in the Tbilisi Declaration which was developed at the international conference of environment educators, sponsored by UNESCO in 1977. Environmental education was defined there as 'learning process that increase people's knowledge and awareness about the environment and associated challenges, develops the necessary skills and expertise to address the challenges, and fosters attitude, motivations, and commitments to make informed decisions and take responsible action' (UNESCO, 1978). According to this declaration, environmental education is seen as a lifelong process that is interdisciplinary and holistic in nature and application. It concerns the interrelationship between human and natural systems and encourages the development of an environmental ethic, awareness, understanding of environmental problems, development of critical thinking and problem solving skills. MacGregor (2003) believes that the Tbilisi definition was based on the definition developed by Stapp et al. (1969), because William Stapp influence in creating and shaping the Tbilisi EE conference (Bartosh, 2003). 
The term environmental awareness has a broad meaning. It not only implies knowledge about environment but also values and necessary skills to solve environmental problems. Moreover, environmental awareness is the initial step ultimately leading to the ability to carry on responsible citizenship behaviour (Sengupta, Das and Maji, 2010). Environmental education is a process of identifying values and clarifying concepts in order to develop skills and added tools necessary to understand and appreciate the inter-relationship among man, his culture and his bio-physical surroundings.

A number of research works have been taken up in this respect. But being a location specific issue, research on environmental education should be undertaken in different parts of the country for developing a clear understanding and perspective of the issues involved. Rajput et al. (1980), made an attempt to identify the awareness of children of primary level, towards the scientific and social environment. The study revealed that only one of the four group ( 2 schools X 2 Class) were significantly different on Environmental awareness at pretest stage, whereas at the post test stage two experimental group were significantly better than the control group Paramjit (1993) conducted a study on "Environmental Awareness among the student of Different SocioEconomic status". The finding revealed that environmental awareness was more among boys of better socioeconomic status whereas among girl, it was observed that the girls of lower socio-economic status had more environmental awareness as compared with boys. Study of Sebastian and Nima (2005) showed that science students have more awareness of biodiversity and its conservation than other students. Fisman, L. (2005), Study Showed that the local environmental awareness found only among students living in high socio-economic neighborhoods.

\section{Justification of the study:}

Over recent decades, global problems relating to degradation of natural resources and pollution have increased dramatically. Natural resources are depleted by excessive use. Fresh water scarcity on a global scale, deforestation, degradation of river areas, soil depletion and loss of biodiversity, are some of the problems that have become a major concern. Air and water pollution have reached such levels that have already resulted in serious health problems, as well as negative impact on the environment, and inevitably influencing prospects for long-term economic growth. Awareness is essential to solve these problems. On the otherhand, without a positive attitude towards environmental education as subject, our Secondary schools will not be able to motivate our future generation to take environment related problems as challenge. That's why the present venture had been made in this direction to study the environmental awareness and attitude towards environmental education among the Secondary School students.

Objectives of the Study:

Major objectives of the present study are:-

1. To study the environmental awareness and attitude towards Environmental Education of Secondary School students of Golaghat district in the state of Assam.

2. To study the environmental awareness and attitude towards Environmental Education of rural and urban Secondary School students of Golaghat district in the state of Assam.

3. To find the relationship between environmental awareness and attitude among the Secondary School students of Golaghat district in the state of Assam.

4. To find the relationship between environmental awareness and socio-economic status, environmental awareness and academic achievement among the Secondary School students of Golaghat district in the state of Assam.

5. To find the relationship between environmental attitude and socio-economic status, environmental attitude and academic achievement among the Secondary School students of Golaghat district in the state of Assam.

\section{Hypothesis of the Study:}

1. There is no significance difference in the environmental awareness among the Secondary School male and female students of Golaghat district in the state of Assam.

2. There is no significance difference in the environmental awareness among the rural and urban Secondary School of Golaghat district in the state of Assam.

3. There is no significance difference in the environmental attitude among the Secondary School male and female students of Golaghat district in the state of Assam.

4. There is no significance difference in the environmental attitude among the rural and urban Secondary School of Golaghat district in the state of Assam. 


\section{Delimitations:}

1. The study is limited to secondary schools in Golaghat district of Assam only.

2. The study is limited to 200 students only.

3. The study is limited to the awareness of students belonging to Secondary Schools in Golaghat district of Assam on environment and their attitude towards environmental education only.

4. The study is limited to the non-cognitive variables like Sex, Socio-economic status and cognitive variable like Academic Achievement, awareness and attitude of the students.

\section{Methodology:}

In view of the objectives of the present study, the researcher has adopted the Descriptive Survey Method. The details are as under:

Sample:

In the present study, a sample of 200 students was selected by adopting the random sampling techniques. Further, selected sample was divided into two segments of 100 students on the basis of sex and settlement. Here, each segments consisting of students of the Secondary Schools in Golaghat district of Assam. Equal representation of students has been ensured for sex and settlement.

Tools Used:

On the basis of the objectives of study following tolls were developed, standardized and used in the present study:

(a) Environmental awareness scale (b) Environmental attitude scale (c) Socio-economic status scale:

Analysis of Data:

The data was statistically analyzed by using 'z' test and Karl Pearson's coefficient of correlation ('r').

IV. Result:

Major findings of the study have been discussed here.

Table 1: Environmental Awareness difference among the Students

\begin{tabular}{|c|c|c|c|}
\hline Statistics & Difference Between & Z value & Significance \\
\hline $\begin{array}{c}\text { Environmental } \\
\text { Awareness }\end{array}$ & $\begin{array}{c}\text { Male and Female Students of } \\
\text { Secondary Schools in Golaghat } \\
\text { District of Assam. }\end{array}$ & 0.02 & Not significant \\
\hline -do- & $\begin{array}{c}\text { Rural and Urban Students of } \\
\text { Secondary Schools in Golaghat } \\
\text { District of Assam. }\end{array}$ & 44.43 & Significant at P < 0.01 \\
\hline
\end{tabular}

Table 1 shows that the ' $Z$ ' value of environmental awareness between the male and female students of Secondary Schools in Golaghat district of Assam are 0.02; which means that there is no any significant difference in regards of environmental awareness between the male and female students. Therefore, the first hypothesis is retained and interpreted that there is no significant difference in environmental awareness among the Secondary School male and female students of Golaghat district in the state of Assam.

But, Table 1 show that the ' $Z$ ' value of environmental awareness between the rural and urban students of Secondary Schools in Golaghat district of Assam is 44.43; which means that there is significant (Significant at $\mathrm{P}<0.01$ ) difference in regards of environmental awareness between the rural and urban students. Therefore, it may conclude that there is no significant difference in environmental awareness among the Secondary School rural and urban students of Golaghat district in the state of Assam. The second hypothesis is rejected and interpreted that there is significant difference in environmental awareness among the Secondary School rural and urban students of Golaghat district in the state of Assam. 
Table 2: Environmental Attitude difference among the Students

\begin{tabular}{|c|c|c|c|}
\hline Statistics & Difference Between & Z value & Significance \\
\hline $\begin{array}{c}\text { Environmental } \\
\text { Attitude }\end{array}$ & $\begin{array}{c}\text { Male and Female Students of } \\
\text { Secondary Schools in Golaghat } \\
\text { District of Assam. }\end{array}$ & 1.85 & Not significant \\
\hline -do- & $\begin{array}{c}\text { Rural and Urban Students of } \\
\text { Secondary Schools in Golaghat } \\
\text { District of Assam. }\end{array}$ & 44.56 & Significant at P < 0.01 \\
\hline
\end{tabular}

Table 2 shows that the ' $Z$ ' value of environmental attitude between the male and female students of Secondary Schools in Golaghat district of Assam are 1.85; which means that there is no significant difference in regards of environmental attitude between the male and female students. Therefore, the third hypothesis is retained and interpreted that there is no any significant difference in environmental attitude among the Secondary School male and female students of Golaghat district in the state of Assam.

But, Table 2 show that the ' $Z$ ' value of environmental attitude between the rural and urban students of Secondary Schools in Golaghat district of Assam is 44.56; which means that there is significant (Significant at P $<0.01)$ difference in regards of environmental attitude between the rural and urban students. It may conclude that there is significant difference in environmental attitude among the Secondary School rural and urban students of Golaghat district in the state of Assam. Therefore, the fourth hypothesis is rejected and interpreted that there is significant difference in environmental attitude among the rural and urban Secondary School students of Golaghat district in the state of Assam.

Table 3: Relation between Environmental Awareness and Environmental Attitude, Socio-economic Status, Academic Achievement

\begin{tabular}{|c|c|c|c|c|c|}
\hline Sample & Relation between & $\begin{array}{l}\text { Coefficient of } \\
\text { correlation(r) }\end{array}$ & $\begin{array}{l}\text { Degrees of } \\
\text { freedom, df }\end{array}$ & p-value & Significance \\
\hline $\begin{array}{l}\text { All students } \\
\quad(200)\end{array}$ & $\begin{array}{l}\text { Environmental } \\
\text { awareness \& } \\
\text { Environmental } \\
\text { Attitude }\end{array}$ & 0.644031 & 198 & $\mathrm{P}<0.01$ & $\begin{array}{c}\text { Strong } \\
\text { Positive Co- } \\
\text { relation. }\end{array}$ \\
\hline -do- & $\begin{array}{l}\text { Socio-economic } \\
\text { status and } \\
\text { Environmental } \\
\text { Awareness }\end{array}$ & 0.661126 & -do- & & $\begin{array}{l}\text { Strong } \\
\text { Positive Co- } \\
\text { relation. }\end{array}$ \\
\hline -do- & $\begin{array}{c}\text { Academic } \\
\text { achievement and } \\
\text { Environmental } \\
\text { Awareness }\end{array}$ & 0.443973 & -do- & & $\begin{array}{l}\text { Positive Co- } \\
\text { relation. }\end{array}$ \\
\hline -do- & $\begin{array}{l}\text { Socio-economic } \\
\text { status and } \\
\text { Environmental } \\
\text { Attitude }\end{array}$ & 0.473788 & -do- & & $\begin{array}{l}\text { Positive Co- } \\
\text { relation. }\end{array}$ \\
\hline -do- & $\begin{array}{c}\text { Academic } \\
\text { achievement and } \\
\text { Environmental } \\
\text { Attitude }\end{array}$ & 0.242332 & -do- & & $\begin{array}{l}\text { Positive Co- } \\
\text { relation. }\end{array}$ \\
\hline
\end{tabular}

Table 3 shows that the value of correlation between the environmental awareness and environmental attitude of Secondary Schools in Golaghat district of Assam has come out 0.64. The value of ' $r$ ' signifies the relation between the two variables is positive and strong. Thus we conclude that if environmental awareness among the Secondary School students rise it will lead to the further in positive attitude towards environmental education.

Table 3 shows that the value of correlation between the socio-economic status and environmental awareness of Secondary Schools in Golaghat district of Assam has come out 0.66. The value of ' $r$ ' signifies the relation between the two variables is positive and strong. Thus we conclude that if socio-economic statuses among the Secondary School students rise it will lead to the further in positive environmental awareness.

Table 3 shows that the value of correlation between the academic achievement and environmental awareness of Secondary Schools in Golaghat district of Assam has come out 0.44. The value of ' $r$ ' signifies the relation between the two variables is positive. Thus we conclude that if academic achievements among the Secondary School students rise it will lead to the further in positive environmental awareness.

Table 3 shows that the value of correlation between the socio-economic status and attitude towards environmental education of Secondary Schools in Golaghat district of Assam has come out 0.47. The value of 
' $r$ ' signifies the relation between the two variables is positive and strong. Thus we conclude that if socioeconomic statuses among the Secondary School students rise it will lead to the further in positive attitude towards environmental education.

Table 3 shows that the value of correlation between the academic achievement and attitude towards environmental education of Secondary Schools in Golaghat district of Assam has come out 0.24. The value of ' $r$ ' signifies the relation between the two variables is positive. Thus we conclude that if academic achievements among the Secondary School students rise it will lead to the further in positive attitude towards environmental education.

\section{Conclusion and Discussion:}

The Secondary School students of Golaghat district of Assam possess strong positive correlation between environmental awareness and attitude towards environmental education. The reason behind this fact can be attributed that environmental education has been introduced as a compulsory subject in the curriculum. The Hon'ble Supreme Court of India $\left(22^{\text {nd }}\right.$ November, 1991) had directed the state governments and education boards to introduce environmental education as a compulsory subject at all levels of education (school to college). The student of Secondary School is now-a-days in touch with the environmental content while learning this subject; the students' ample knowledge and information about environmental concepts, its importance, problems and solutions.

There is significant difference in environmental awareness among Secondary School students with respect to the settlement. The students of rural and urban Secondary School are not equally aware about the environment. The result of the conducted by Shahnawaj (1990) on 'Environmental awareness and environmental attitude of secondary and higher secondary school teachers and students' is also in line with the findings of the present study.

\section{Educational Implications:}

To protect and conserve the environment, emphasis should be given to Environmental Education in both formal and non-formal system of education. In formal system of education, teachers play a very significant role in developing a greater awareness about environment among students. This may bring radical change among the students in the way of thinking, living and working.

\section{References:}

[1] Trivedi, P.R. and Raj, G. (1992): Concepts in Education. Akashdeep Publishing House, New Delhi.

[2] The National Association of Conservation District (NACD): Environmental education at a glance. League City, Texas; 1998.

[3] UNESCO (1978): Tbilisi Declaration (Final report of the International conference of EE: Tbilisi (USSR), 11-26 October 1977). Paris: UNESCO.

[4] Bartosh, Oksana. (2003): Environmental Education: Improving Students Achievement. A thesis submitted in partial fulfillment of the requirements for the degree of Master of Environmental Studies, The Evergreen State College, June 2003. P. 4.

[5] Sengupta, M., Das, J. and Maji, R. K. (2010): Environmental Awareness and Environmental Related Behaviour of Twelfth Grade Students in Kolkata: Effects of Stream and Gender. Anwesa, Vol.5, No. 1-8.

[6] Rajput, J. S., Saxena, A.B. and Jadhao, V.G. (1980): A research Study in Environmental Approach of Teaching at Primary Level. Third Survey of Research in Education (1978-1983), Edited by M.B. Buch, NCERT, 1987.

[7] Sengupta et al.(2010): Environmental Awareness and Environment Related Behaviour of Twelfth Grade Students in Kolkata: Effects of Stream and Gender, Anwesa, Vol. $5: 1$ - 8, January 2010.

[8] Shahnawaj (1990): Environmental awareness and environmental attitude of secondary and higher secondary school teachers and students, In NCERT (ed.) Fifth Survey of Educational Research - II, p. 1759. 